\title{
PENERAPAN MEDIA VIDEO DENGAN MODEL $E$-LEARNING DALAM UPAYA MENINGKATKAN HASIL BELAJAR TEMATIK PADA SISWA KELAS III MI NU 33 JOHOREJO KECAMATAN GEMUH KABUPATEN KENDAL TAHUN PELAJARAN 2019/2020
}

\author{
AHMAD DURJANI \\ MI NU 33 Johorejo Kendal \\ e-mail : durjaniahmad@gmail.com
}

\begin{abstract}
ABSTRAK
Penelitian ini merupakan upaya dalam meningkatan hasil belajar Tematik melalui model $e$ learning dengan media video pada siswa Kelas III MI NU 33 Johorejo Kecamatan Gemuh Kabupaten Kendal. Hal ini dikarenakan guru hanya memberi tugas seperti mencatat dan membaca tidak menjamin siswa akan belajar di rumah. Pemberian tugas tanpa adanya materi pembelajaran yang disampaikan guru menyebabkan hasil belajar Tematik masih terbilang rendah atau masih dibawah KBM yaitu 75. Penelitian ini menggunakan Penelitian Tindakan Kelas (PTK) berupa penerapan model e-learning dengan media video dengan tujuan meningkatkan hasil belajar siswa Kelas III MI NU 33 Johorejo Kecamatan Gemuh Kabupaten Kendal yang terdiri dari dua siklus dan setiap siklus tediri dari perencanaan, pelaksanaan, pengamatan, dan refleksi. Subjek penelitian pada siswa Kelas III MI NU 33 Johorejo Kecamatan Gemuh Kabupaten Kendal. Jumlah siswa 29 siswa terdiri dari 10 siswa laki-laki dan 19 siswa perempuan. Hasil penelitian menunjukkan bahwa penerapan model e-learning dengan media video dapat meningkatkan hasil belajar Tematik pada siswa Kelas III MI NU 33 Johorejo Kecamatan Gemuh Kabupaten Kendal. Dilihat dari hasil Pra siklus siswa yang tuntas KBM hanya 14 siswa $(48,3 \%)$, dan 15 siswa $(51,7 \%)$ yang belum tuntas. Pada siklus I terdapat 24 siswa $(82,8 \%)$ yang tuntas dan 5 siswa $(17,2 \%)$ yang belum tuntas, dan pada siklus II terdapat 26 siswa $(89,7 \%)$ yang tuntas dan terdapat 3 siswa $(10,3 \%)$ yang belum tuntas. Dari peningkatan hasil belajar tersebut penelitian tindakan kelas ini di hentikan di siklus II karena telah mencapai kriteriaketuntasan klasikalyaitu $\geq 85 \%$ dari jumlah seluruh siswa tuntas belajar dan dinyatakan berhasil untuk meningkatkan hasil belajar Tematik pada siswa Kelas III MI NU 33 Johorejo Kecamatan Gemuh Kabupaten Kendal Tahun Pelajaran 2019/2020.
\end{abstract}

Kata Kunci: Hasil belajar Tematik, Model E-Learning, Media Video.

\section{PENDAHULUAN}

Belajar merupakan proses untuk memperoleh perubahan tingkah laku sebagai hasil pengalaman dalam interaksi dengan lingkungan. Sebagai bukti hasil dari proses pembelajaran adalah perubahan tingkah laku. Seorang dikatakan belajar apabila terjadi perubahan pada dirinya sebagai akibat adanya latihan dan pengalaman melalui interaksi dengan lingkungan (Hamid, 2013:5). Seorang pendidik dituntut untuk kreatif dalam penyampaiannya, memberikan kesan peserta didik serta, menciptakan komunikasi antar peserta didik, dan menjadikan siswa yang aktif saat proses pembelajaran sehingga dapat mencapai tujuan pembelajaran berupa ketuntasan hasil belajar siswa.

Berdasarkan hasil wawancara dengan guru di MI NU 33 Johorejo Kecamatan Gemuh Kabupaten Kendal, proses Kegiatan Belajar Mengajar belum juga dilakukan karena kebijakan yang ditetapkan pemeritah terkait wabah covid-19 untuk menerapkan pembatasan sosial guna mencegah penyebaran virus corona, dengan menerapkan pembelajaran jarak jauh dari rumah masing-masing. Proses pembelajaran jarak jauh sudah dilakukan dari tanggal 16 Maret 2020. Sistem belajar yang semula tatap muka menjadi sistem daring atau online dengan memanfaatkan teknologi.

Permasalahan yang muncul, guru hanya memberikan tugas, seperti mencatat dan membaca tidak menjamin siswa atau siswi akan belajar dirumah, menjadikan berkurangnya ketertarikan siswa untuk mengikuti pembelajaran tematik. Sehingga hasil belajar tidak tercapai 
sesuai dengan Ketuntasan Belajar Minimal (KBM) yang ditentukan. Menurut hasil wawancara dengan salah satu guru MI NU 33 Johorejo Kecamatan Gemuh Kabupaten Kendal, masih banyak siswa yang nilainya di bawah KBM yaitu 75, dari 29 siswa, ada 14 siswa tuntas $(48,3 \%)$ dan 15 siswa tidak tuntas $(51,7 \%)$. Rendahnya persentase siswa yang mencapai Ketuntasan Belajar Minimal (KBM) menunjukkan bahwa ketuntasan hasil belajar siswa secara klasikal di kelas tersebut masih belum optimal sehingga perlu ditingkatkan.

Berdasarkan masalah diatas, dapat disimpulkan bahwa rendahnya hasil belajar tematik dikarenakan pembelajaran yang kurang menarik, hanya pemberian tugas tanpa adanya materi pembelajaran yang disampaikan guru. Seorang guru harus kreatif dalam memilih media pembelajaran yang disesuaikan dengan karakteristik siswa. Salah satu cara untuk mengatasi permasalahan tersebut adalah dengan menerapkan model $e$-learning dengan media Video. Hal ini akan memudahkan siswa dalam menerima materi secara detail, dan dapat diputar berulangulang untuk memahami materi yang disampaikan.

Model e-learning merupakan pembelajaran yang disusun dengan tujuan menggunakan sistem elektronik atau komputer sehingga mampu mendukung proses pembelajaran (Michael, 2013: 27), proses pembelajaran jarak jauh dengan menggabungkan prinsip-prinsip dalam proses pembelajaran dengan teknologi (Chandrawati,2010).

Media merupakan bagian yang tak terpisahkan untuk memudahkan serta mewujudkan tercapainya pemahaman materi kepada siswa sehingga seorang guru diharapkan mampu menggunakan media untuk menciptakan suasana pembelajaran efektif,kreatif dan menyenangkan. Sedangkan media pembelajaran merupakan suatu bagian yang tak terpisahkan dalam menyampaikan pesan, dapat merangsang pikiran, perasaan, dan kemauan peserta didik sehingga dapat mendorong terciptanya proses belajar pada diri peserta didik (Kastolani, 2014:222).

Video sebagai media audio-visual yang menampilkan gerak, semakin lama semakin populer dalam masyarakat. Pesan yang disajikan bisa bersifat fakta (kejadian atau peristiwa penting, berita) maupun fiktif (seperti misalnya cerita) bisa bersifat informatif, edukatif maupun instruksional. Sebagian besar tugas film dapat digantikan oleh video. Tapi ini tidak berarti bahwa video akan meggantikan kedudukan film (Sadiman, 2012:74).

Berdasarkan permasalahan yang timbul, peneliti bermaksud untuk melaksanaan penelitian dengan judul "Penerapan Media Video Dengan Model E-Learning Dalam Upaya Meningkatkan Hasil Belajar Tematik Pada Siswa Kelas III MI NU 33 Johorejo Kecamatan Gemuh Kabupaten Kendal Tahun Pelajaran 2019/2020”.

\section{METODE PENELITIAN}

Rancangan penelitian ini menggunakan tindakan kelas (PTK) tindakan yang dirancang berupa penerapan model e-learning dengan media video dengan tujuan meningkatkan hasil belajar siswa Kelas III MI NU 33 Johorejo Kecamatan Gemuh Kabupaten Kendal. Tahapan dalam rancangan penelitian tindakan kelas dilakukan dengan perencanaan, pelaksanaan, pengamatan, dan melakukan refleksi pada setiap siklus sampai meningkatnya hasil pembelajaran hingga penelitian dihentikan.

Penelitian tindakan kelas ini menggunakan penelitian kolaboratif. Ibu Siti Purwati, S.Pd.I. sebagai rekan guru kelas yang melakukan kegiatan proses pembelajaran dan peneliti sebagai pengamat. Peneliti membantu guru dalam menyiapkan media video pembelajaran dan melakukan pengamatan terhadap kegiatan yang dilakukan guru dan siswa menggunakan model e-learning dengan media video. Waktu pelaksanaan penelitian sebagai berikut kegiatan siklus I pada 14 Mei 2020 dan siklus II pada tanggal 18 Mei 2020. 


\section{HASIL DAN PEMBAHASAN}

\section{A. Pelaksanaan Penelitian}

Penelitian tindakan kelas ini dilaksanakan 2 siklus penelitian. Masing-masing siklus terdiri dari 4 tahap yaitu perencanaan, pelaksanaan, pengamatan, dan refleksi. Uraian dari dua Siklus tersebut adalah sebagai berikut:

\section{Deskrtematiki Siklus 1}

\section{1) Perencanaan}

Peneliti menyusun perencanaan kegiatan yang dilakukan sebagai berikut:

a) Membuat rencana pelaksanaan pembelajaran (RPP) dengan menggunakan model $e$ learning dengan media video

b) Membuat media video materi bentuk-bentuk energi yang akan digunakan dalam pembelajaran

c) Mempersiapkan soal dari google form yang diberikan pada setiap siklus yang disusun oleh peneliti

\section{2) Pelaksanaan}

Penelitian Siklus I dilaksanakan pada hari Kamis, 14 Mei 2020 pada Kelas III MI NU 33 Johorejo Kecamatan Gemuh Kabupaten Kendal, dengan jumlah siswa sebanyak 29 siswa. Materi yang diajarkan pada tahap ini tentang bentuk-bentuk energi.Pelaksanaan sesuai dengan pembelajaran yang tertulis pada RPP dan tahap perencanaan. Kegiatan pembelajaran terdiri dari 3 kegiatan yaitu: pendahuluan, inti dan penutup.

\section{3) Pengamatan}

Peneliti melakukan pengamatan melalui foto atau tugas yang diberikan kepada guru. Tindakan ini untuk mengamati proses belajar yang bertujuan untuk memperoleh data hasil kinerja guru dan keaktifan siswa pada saat pembelajaran online.

\section{4) Refleksi}

Peneliti mempertimbangkan hasil dari Siklus I. Hasil refleksi akan dipergunakan untuk memperbaiki kinerja guru pada tahap siklus II dan seterusnya. Peneliti selalu komunikasi dengan guru untuk mengetahui proses pembelajaran dan mencari solusi untuk perbaikan, sehingga menjadi acuan perbaikan pada siklus II dan seterusnya.

Siklus I menujukkan hasil pembelajaran yang cukup memuaskan dibandingkan pembelajaran Pra Siklus, akan tetapi hasil pembelajaran belum mencapai persentase klasikal $\geq 85 \%$. Siswa yang tuntas pada Pra Siklus sebanyak 14 siswa (48,3\%), pada Siklus I meningkat sebanyak 24 siswa $(82,8 \%)$. Nilai rata-rata siswa Pra Siklus ke Siklus I juga meningkat yaitu dari 71,2 menjadi 87,9 . Sisanya yaitu 5 siswa yang masih dinyatakan belum tuntas dalam mengikuti pembelajaran. Hal ini disebabkan oleh beberapa hal antara lain:

a) Tidak semua siswa online saat proses pembelajaran

b) Keadaan yang kurang kondusif ketika berada di rumah

Hambatan yang ada pada Siklus I menjadi acuan perbaikan yang dilakukan pada Siklus II. Perbaikan yang dilakukan antara lain:

a) Guru sebaiknya menghubungi wali murid agar tetap memantau perkembangan siswa dan tetap belajar dilakukan secara online

b) Guru memberikan waktu atau sebelumnya sudah diberi tau bahwa tugas atau pembelajaran akan di mulai setiap jam 7 seperti pembelajaran yang dilakukan di sekolah, agar siswa standbay dengan handphone

c) Guru memberikan batas maksimal pengumpulan tugas paling tidak 2 x 24 jam dari awal pembelajaran, untuk siswa yang terkendala paket data. 


\section{Deskrtematiki Siklus II}

1) Perencanaan

Pada tahap ini peneliti menyusun perencanaan kegiatan yang dilakukan sebagai berikut:

a) Membuat rencana pelaksanaan pembelajaran (RPP) dengan menggunakan model $e$ learning dengan media video

b) Membuat media video materi macam-macam energi yang akan digunakan dalam pembelajaran

c) Mempersiapkan soal dari google form yang disusun oleh peneliti

\section{2) Pelaksanaan}

Penelitian Siklus II dilaksanakan pada hari Senin 18 Mei 2020 pada kelas III MI NU 33 Johorejo Kecamatan Gemuh Kabupaten Kendal, dengan jumlah siswa sebanyak 29 siswa. Materi yang diajarkan pada tahap ini tentang macam-macam energi. Pelaksanaan sesuai dengan pembelajaran yang tertulis pada RPP dan tahap perencanaan. Kegiatan pembelajaran terdiri dari 3 kegiatan yaitu: pendahuluan, inti dan penutup.

\section{3) Pengamatan}

Peneliti melakukan pengamatan melalui foto atau tugas yang diberikan kepada guru.Tindakan ini untuk mengamati proses belajar yang bertujuan untuk memperoleh data hasil kinerja guru dan keaktifan siswa pada saat pembelajaran online.

\section{4) Refleksi}

Pelaksanaan pembelajaran pada Siklus II mengalami peningkatan, siswa mengikuti pembelajaran dengan baik. Kelemahan-kelemahan yang terjadi pada Siklus I juga dapat diatasi pada Siklus II ini.

Penelitian dihentikan pada Siklus II karena hasil belajar siswa sudah menunjukkan indikator ketuntasan klasikal yang diharapkan yaitu $\geq 85 \%$ siswa tuntas belajar.

\section{B. Deskrtematiki Hasil Penelitian}

\section{Deskrtematiki Hasil Pra Siklus}

Tahap Pra Siklus dilakukan sebelum peneliti melaksanakan Siklus I. Hasil dari observasi Pra Siklus terdapat masalah pembelajaran TEMATIK. Hasil belajar TEMATIK masih dibawah Ketuntasan Belajar Minimal (KBM) yaitu 75. Adapun nilai hasil ulangan harian (Pra Siklus) dapat di lihat pada Tabel 1.

Tabel 1. Nilai Ulangan Harian Siswa Pra Siklus

\begin{tabular}{|l|l|l|l|}
\hline No & Arman Yuliyanto & Nilai & Keterangan \\
\hline 1 & Ahmad Haris Miftahudin & 60 & TIDAK TUNTAS \\
\hline 2 & Agam Marna Alvaro & 75 & TUNTAS \\
\hline 4 & Ainiyatuz Zakiyah & 80 & TUNTAS \\
\hline 5 & Ahmad Maulana Zaeni & 65 & TIDAK TUNTAS \\
\hline 6 & Alexa Najwa Azahra & 90 & TUNTAS \\
\hline 7 & Echa Hilfatum Marha & 60 & TIDAK TUNTAS \\
\hline 8 & Fanzela Famimuza Wijaya & 80 & TUNTAS \\
\hline 9 & Hayi Lana & 70 & TIDAK TUNTAS \\
\hline
\end{tabular}


ACTION : Jurnal Inovasi Penelitian Tindakan Kelas dan Sekolah

Vol 1. No 1. Juli 2021 e-ISSN : 2798-5733 P-ISSN : 2798-5741

\begin{tabular}{|l|l|l|l|}
\hline 10 & Hendra Permana & 50 & TIDAK TUNTAS \\
\hline 11 & Hannadi Hindi & 55 & TIDAK TUNTAS \\
\hline 12 & Irfan Nur Miftakhudin & 65 & TIDAK TUNTAS \\
\hline 13 & Arman Yuliyanto & 85 & TUNTAS \\
\hline 15 & Kaila Wahda Zilivia & 90 & TUNTAS \\
\hline 16 & Muhamad Musyahidin & 70 & TIDAK TUNTAS \\
\hline 17 & Nafis Ulin Najwa & 75 & TUNTAS \\
\hline 18 & Nur Nadaa Syafiqoh & 70 & TUDAK Ihsan \\
\hline 19 & Rizka Bagus Maulana & 90 & TUNTAS \\
\hline 20 & Ana Afifatun Nissak & 60 & TIDAK TUNTAS \\
\hline 21 & Airin Rifdatul Muna & 65 & TIDAK TUNTAS \\
\hline 22 & Arina Husna Fauziyah & 80 & TUNTAS \\
\hline 23 & Afina Salsabila Rosyada & 60 & TIDAK TUNTAS \\
\hline 24 & Dhiya Hasna Febiyanti & 75 & TUNTAS \\
\hline 25 & Indy Qotrun Najah & 90 & TUNTAS \\
\hline 26 & Kunti Wafa Sakinah & 40 & TIDAK TUNTAS \\
\hline 27 & Lilif Cholifatus Salamah & 50 & TIDAK TUNTAS \\
\hline 28 & Mita Laelatul Fitri & 85 & TUNTAS \\
\hline 29 & Maulida Rifka Syahida & 55 & TIDAK TUNTAS \\
\hline Nilai Tertinggi & 90 & \\
\hline Nilai Terendah & 40 & \\
\hline Rata-Rata & 71,2 & \\
\hline
\end{tabular}

Keterangan

Tuntas : 14 siswa Tidak Tuntas : 15 siswa

Presentase Ketuntasan dihitung berdasarkan rumus berikut :

$$
\begin{gathered}
\text { Presentase Ketuntasan }=\frac{\text { Jumlah Siswa Tuntas }}{\text { Jumlah Seluruh Siswa }} \times 100 \% \\
=\frac{14}{29} \times 100 \% \\
=48,3 \%
\end{gathered}
$$

Berdasarkan Tabel 1 dapat disimpulkan nilai rata-rata Kelas III MI NU 33 Johorejo Kecamatan Gemuh Kabupaten Kendal adalah 71,2, dari siswa yang tuntas ( mencapai KBM) ada 14 siswa (48,3\%), sedangkan yang belum tuntas ada 15 siswa (51,7\%). Secara klasikal pada siklus ini belum tuntas belajar, karena siswa yang memperoleh nilai $\geq 75$ (nilai KBM) hanya mencapai 48,3\% dari siswa keseluruhan. Hasil presentase belum mencapai kriteria ketuntasan klasikal yaitu $\geq 85 \%$ dari jumlah seluruh siswa tuntas belajarnya, jadi harus dilaksanakan Siklus selanjutnya yaitu Siklus I. Diagram pada gambar 1 dapat dilihat bahwa siswa yang telah tuntas 
sebanyak 14 siswa dengan presentase 48,3\% dan siswa yang tidak tuntas sebanyak 15 siswa dengan presentase $51,7 \%$.

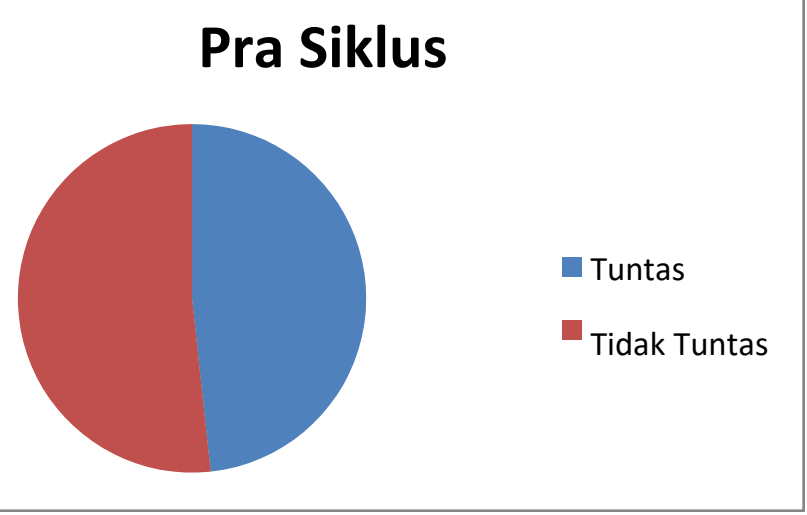

Gambar 1. Diagram Ketuntasan Hasil Belajar Siswa Pra Siklus

\section{Deskrispi Hasil Siklus I}

Penelitian pada Siklus I dilaksanakan Kamis, 14 Mei 2020, pada Kelas III MI NU 33 Johorejo Kecamatan Gemuh Kabupaten Kendal dengan jumlah 29 siswa yang dilaksanakan secara online. Materi pada Siklus I adalah Bentuk-Bentuk Energi. Berikut nilai hasil belajar Siklus I:

Tabel. 2 Nilai Hasil Belajar Siklus I

\begin{tabular}{|l|l|l|l|}
\hline No & Nama & Nilai & Keterangan \\
\hline 1 & Arman Yuliyanto & 90 & TUNTAS \\
\hline 3 & Ahmad Haris Miftahudin & 100 & TUNTAS \\
\hline 4 & Agam Marna Alvaro & 90 & TUNTAS \\
\hline 5 & Ahmad Maulana Zaeni & 80 & TUNTAS \\
\hline 6 & Aisyah Ayu Shalma Lestari & 100 & TUNTAS \\
\hline 7 & Alexa Najwa Azahra & 90 & TUNTAS \\
\hline 8 & Echa Hilfatum Marha & 90 & TUNTAS \\
\hline 9 & Fanzela Famimuza Wijaya & 80 & TUNTAS \\
\hline 10 & Hayi Lana & 80 & TUNTAS \\
\hline 11 & Hendra Permana & 100 & TUNTAS \\
\hline 12 & Hannadi Hindi & 70 & TIDAK TUNTAS \\
\hline 13 & Irfan Nur Miftakhudin & 70 & TIDAK TUNTAS \\
\hline 14 & Kaila Wahda Zilivia & 100 & TUNTAS \\
\hline 15 & Muhamad Musyahidin & 90 & TUNTAS \\
\hline 16 & Muhamad Nasrul Ihsan & 90 & TUNTAS \\
\hline 17 & Nafis Ulin Najwa & 100 & TUNTAS \\
\hline 18 & Nur Nadaa Syafiqoh & 100 & TUNTAS \\
\hline
\end{tabular}


Vol 1. No 1. Juli 2021 e-ISSN : 2798-5733 P-ISSN : 2798-5741

\begin{tabular}{|l|l|l|l|}
\hline 19 & Rizka Bagus Maulana & 80 & TUNTAS \\
\hline 20 & Ana Afifatun Nissak & 70 & TIDAK TUNTAS \\
\hline 21 & Airin Rifdatul Muna & 100 & TUNTAS \\
\hline 23 & Arina Husna Fauziyah & 90 & TUNTAS \\
\hline 24 & Afina Salsabila Rosyada & 80 & TUNTAS \\
\hline 25 & Dhiya Hasna Febiyanti & 60 & TIDAK TUNTAS \\
\hline 26 & Kunti Wafa Sakinah & 700 & TUNTAS \\
\hline 27 & Lilif Cholifatus Salamah & 90 & TUNTAK TUNTAS \\
\hline 28 & Mita Laelatul Fitri & 90 & TUNTAS \\
\hline 29 & Maulida Rifka Syahida & 100 & TUNTAS \\
\hline Nilai Tertinggi & & & 100 \\
\hline Nilai Terendah & & 60 \\
\hline Rata-Rata & &
\end{tabular}

Keterangan

Tuntas : 24 siswa Tidak Tuntas : 5 siswa

Presentase Ketuntasan dihitung berdasarkan rumus berikut :

$$
\begin{gathered}
\text { Presentase Ketuntasan }=\frac{\text { Jumlah Siswa Tuntas }}{\text { Jumlah Seluruh Siswa }} \times 100 \% \\
=\frac{24}{29} \times 100 \% \\
=82,4 \%
\end{gathered}
$$

Berdasarkan Tabel 2 dapat disimpulkan nilai rata-rata Kelas III MI NU 33 Johorejo Kecamatan Gemuh Kabupaten Kendal adalah 87,9 dari siswa yang tuntas ( mencapai KBM) ada 24 siswa (82,8\%), sedangkan yang belum tuntas ada 5 siswa (17,2\%). Secara klasikal pada siklus ini belum tuntas belajar, karena siswa yang memperoleh nilai $\geq 75$ (nilai KBM) mencapai $82,8 \%$ dari siswa keseluruhan. Hasil presentase belum mencapai kriteria ketuntasan klasikal yaitu $\geq 85 \%$ dari jumlah seluruh siswa tuntas belajarnya, jadi harus dilaksanakan Siklus selanjutnya yaitu Siklus II.

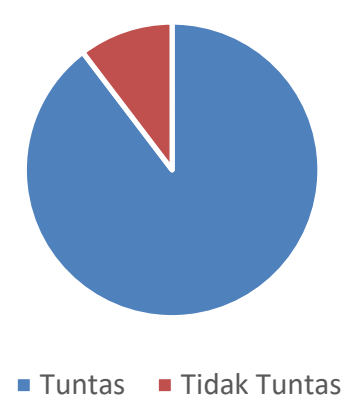

Gambar 2. Diagram Ketuntasan Hasil Belajar Siswa Siklus I 
Diagram di atas dapat dilihat bahwa dari 29 siswa yang telah tuntas sebanyak 24 siswa dengan presentase $82,8 \% \%$ dan siswa yang tidak tuntas sebanyak 5siswa dengan prsentase $17,2 \%$.

\section{Deskrtematiki Hasil Siklus II}

Penelitian pada Siklus II dilaksanakan Senin, 18 Mei 2020, pada Kelas III MI NU 33 Johorejo Kecamatan Gemuh Kabupaten Kendal dengan jumlah 29 siswa yang dilaksanakan secara online. Materi pada Siklus II adalah Macam-Macam Energi. Berikut nilai hasil belajar Siklus II:

Tabel. 3 Nilai Hasil Belajar Siklus II

\begin{tabular}{|c|c|c|c|}
\hline No & Nama & Nilai & Keterangan \\
\hline 1 & Arman Yuliyanto & 100 & TUNTAS \\
\hline 2 & Ahmad Haris Miftahudin & 90 & TUNTAS \\
\hline 3 & Agam Marna Alvaro & 100 & TUNTAS \\
\hline 4 & Ainiyatuz Zakiyah & 100 & TUNTAS \\
\hline 5 & Ahmad Maulana Zaeni & 90 & TUNTAS \\
\hline 6 & Aisyah Ayu Shalma Lestari & 90 & TUNTAS \\
\hline 7 & Alexa Najwa Azahra & 70 & TIDAK TUNTAS \\
\hline 8 & Echa Hilfatum Marha & 90 & TUNTAS \\
\hline 9 & Fanzela Famimuza Wijaya & 100 & TUNTAS \\
\hline 10 & Hayi Lana & 80 & TUNTAS \\
\hline 11 & Hendra Permana & 90 & TUNTAS \\
\hline 12 & Hannadi Hindi & 90 & TUNTAS \\
\hline 13 & Irfan Nur Miftakhudin & 80 & TUNTAS \\
\hline 14 & Kaila Wahda Zilivia & 100 & TUNTAS \\
\hline 15 & Muhamad Musyahidin & 100 & TUNTAS \\
\hline 16 & Muhamad Nasrul Ihsan & 80 & TUNTAS \\
\hline 17 & Nafis Ulin Najwa & 100 & TUNTAS \\
\hline 18 & Nur Nadaa Syafiqoh & 100 & TUNTAS \\
\hline 19 & Rizka Bagus Maulana & 70 & TIDAK TUNTAS \\
\hline 20 & Ana Afifatun Nissak & 80 & TUNTAS \\
\hline 21 & Airin Rifdatul Muna & 80 & TUNTAS \\
\hline 22 & Arina Husna Fauziyah & 70 & TIDAK TUNTAS \\
\hline 23 & Afina Salsabila Rosyada & 80 & TUNTAS \\
\hline 24 & Dhiya Hasna Febiyanti & 90 & TUNTAS \\
\hline
\end{tabular}


Vol 1. No 1. Juli 2021 e-ISSN : 2798-5733 P-ISSN : 2798-5741

\begin{tabular}{|l|l|l|l|}
\hline 25 & Indy Qotrun Najah & 100 & TUNTAS \\
\hline 26 & Kunti Wafa Sakinah & 80 & TUNTAS \\
\hline 27 & Lilif Cholifatus Salamah & 90 & TUNTAS \\
\hline 28 & Mita Laelatul Fitri & 100 & TUNTAS \\
\hline 29 & Maulida Rifka Syahida & 90 & TUNTAS \\
\hline Nilai Tertinggi & & 100 \\
\hline Nilai Terendah & 70 \\
\hline Rata-Rata & 89 \\
\hline
\end{tabular}

Keterangan Tuntas $=26$

Tidak Tuntas $=3$

Presentase Ketuntasan dihitung berdasarkan rumus berikut :

$$
\begin{gathered}
\text { Presentase Ketuntasan }=\frac{\text { Jumlah Siswa Tuntas }}{\text { Jumlah Seluruh Siswa }} \times 100 \% \\
=\frac{26}{29} \times 100 \% \\
=89,7 \%
\end{gathered}
$$

Berdasarkan Tabel 4.3 dapat disimpulkan nilai rata-rata Kelas III MI NU 33 Johorejo Kecamatan Gemuh Kabupaten Kendal adalah 88,96 dari siswa yang tuntas ( mencapai KBM) ada 26 siswa $(89,7 \%)$, sedangkan yang belum tuntas ada 3 siswa (10,3\%). Pada Siklus II

pembelajaran sudah tuntas, karena secara klasikal pada siklus ini siswa yang memperoleh nilai $\geq 75$ (nilai KBM) mencapai 89,7\% dari siswa keseluruhan. Hasil presentase sudah mencapai kriteria ketuntasan klasikal yaitu $\geq 85 \%$ dari jumlah seluruh siswa tuntas belajarnya, jadi penelitian dihentikan pada Siklus II.

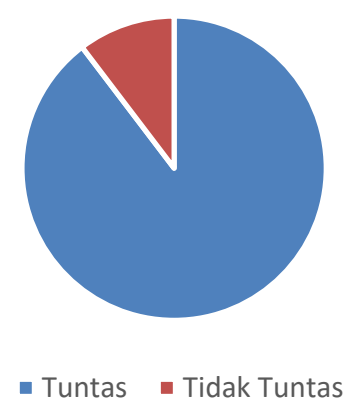

\section{Gambar 3. Diagram Ketuntasan Hasil Belajar Siswa Siklus II}

Diagram di atas dapat dilihat bahwa siswa yang telah tuntas sebanyak 26 siswa dengan presentase ketuntasan $89,7 \%$ dan siswa yang belum tuntas sebanyak 3 siswa dengan presentase $10,3 \%$.

\section{Pembahasan Hasil Penelitian}

Pembelajaran TEMATIK menggunakan model e-learning dan media video memiliki pengaruh terhadap peningkatan hasil belajar siswa. Hasil penelitian dapat dilihat pada tabel 4: 
Tabel 4. Rekapitulasi Hasil Belajar Siswa

\begin{tabular}{|c|c|c|c|c|}
\hline Siklus & $\begin{array}{c}\text { Rata- } \\
\text { Rata }\end{array}$ & Kategori & Jumlah & Persentase \\
\hline Pra Siklus & \multirow{2}{*}{71,2} & Tuntas & 14 & $48,3 \%$ \\
\cline { 3 - 5 } & & Tidak Tuntas & 15 & $51,7 \%$ \\
\hline I & 87,9 & Tuntas & 24 & $82,8 \%$ \\
\cline { 3 - 5 } & & Tidak Tuntas & 5 & $17,2 \%$ \\
\hline II & 89 & Tuntas & 26 & $89,7 \%$ \\
\cline { 3 - 5 } & & Tidak Tuntas & 3 & $10,3 \%$ \\
\hline
\end{tabular}

Berdasarkan Tabel 4. menunjukkan adanya peningkatan hasil belajar setelah dilakukan penindakan. Proses pembelajaran dilakukan dengan menggunakan model E-Learning dan media video. Tabel 4. menunjukan bahwa hasil pembelajaran Pra Siklus adalah 14 siswa $(48,3 \%)$ tuntas, dan 15 siswa $(51,7 \%)$ tidak tuntas dengan nilai rata-rata 71,2 . Hasil tersebut belum memenuhi kriteria ketuntasan yang telah ditetapkan, maka harus dilakukan penelitian pada Siklus I. Tabel 4. menunjukkan bahwa hasil pembelajaran Siklus I adalah 24 siswa $(82,8 \%)$ tuntas, dan 5 siswa $(17,2 \%)$ tidak tuntas dengan nilai rata-rata 87,9. Hasil tersebut belum memenuhi kriteria ketuntasan yang telah ditetapkan, maka harus dilakukan penelitian pada Siklus II dengan materi dan waktu berbeda.

Hasil belajar pada Siklus II terdapat 26 siswa $(89,7 \%)$ tuntas, dan 3 siswa $(10,3 \%)$ tidak tuntas dengan nilai rata-rata 89. Hasil data tersebut dapat diketahui nilai hasil belajar siswa Siklus I ke Siklus II mengalami peningkatan 6,9\%. Pelaksanaan pembelajaran pada Siklus II secara klasikal siswa yang memperoleh nilai $\geq 75$ (nilai $\mathrm{KBM}$ ) mencapai $89,7 \%$ dari siswa keseluruhan. Hasil presentase sudah mencapai kriteria ketuntasan klasikal yaitu $\geq 85 \%$ dari jumlah seluruh siswa tuntas belajarnya. Siswa yang belum tuntas pada Siklus II akan diberikan tindakan mandiri berupa latihan-latihan atau remidiasi oleh guru sehingga diharapkan semua siswa dapat tuntas belajar. Hasil penelitian dapat digambarkan menggunakan gambar grafik 4:

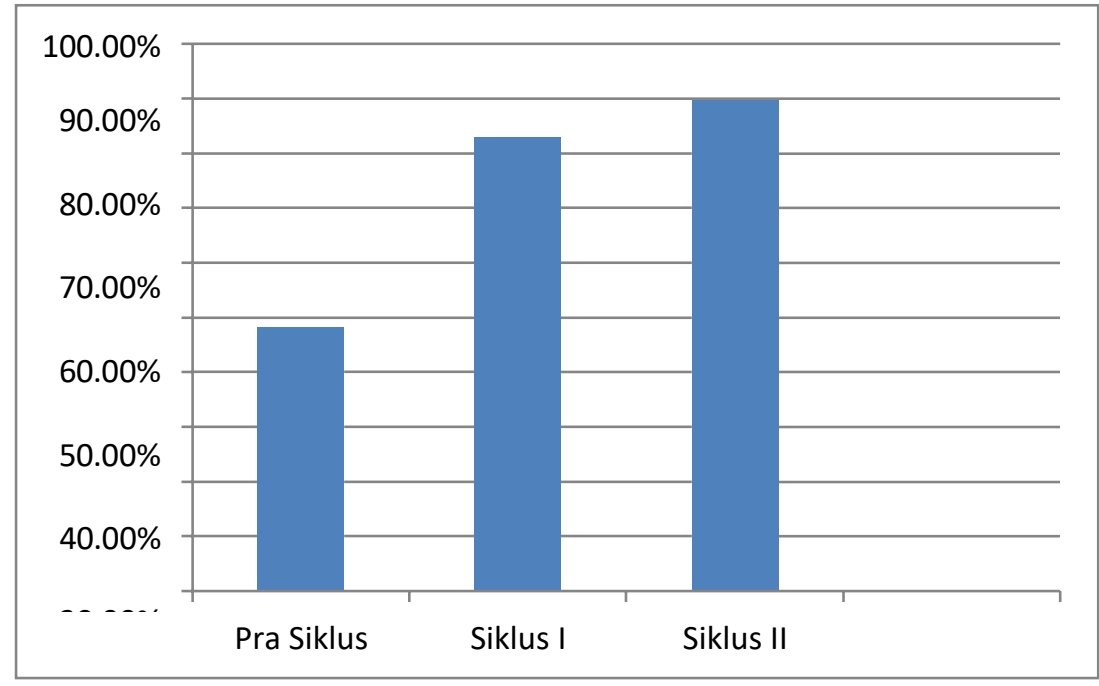

Gambar 4. Grafik Ketuntasan Belajar Siswa 
Gambar 4. menunjukkan hasil belajar siswa setelah diterapkan model $e$-learning dan media video terjadi peningkatan ketuntasan belajar Pra Siklus 48,3\% siswa tuntas belajar, Siklus I 82,8\% siswa tuntas belajar, dan Siklus II 89,7\% siswa tuntas belajar. Peningkatan siswa tuntas belajar dari Pra Siklus ke Siklus I 34,5\%, dan Siklus I ke Siklus II 6,9\%. Pembahasan dapat digambarkan menggunakan Diagram 4.5:

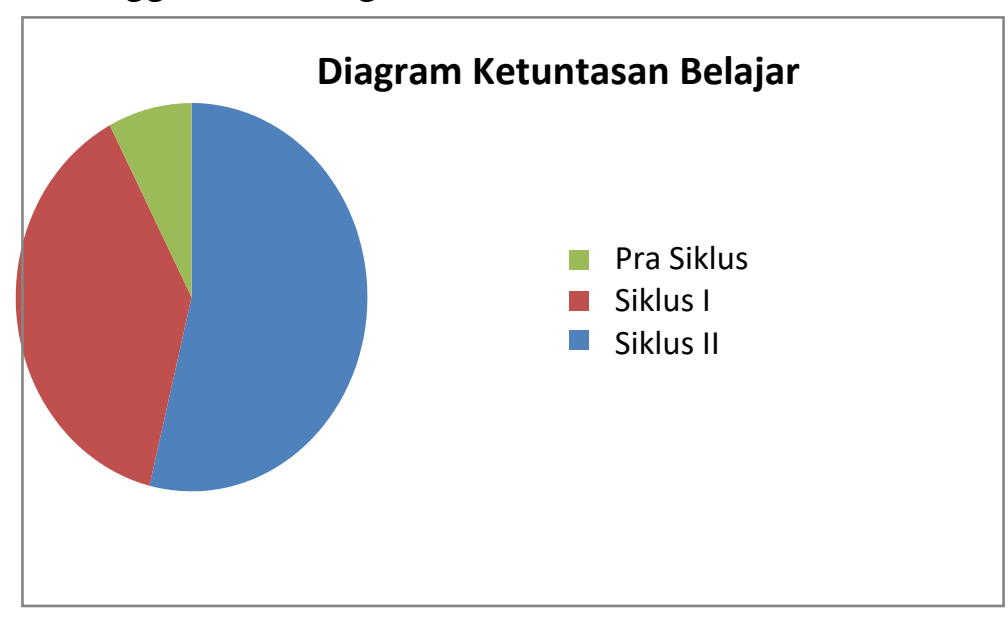

Gambar 5. Diagram Ketuntasan Siswa

Gambar 5 menunjukkan bahwa hasil belajar siswa setalah diterapkan model e-learning dan media video terjadi peningkatan dari Pra Siklus 48,3\% siswa tuntas belajar, Siklus I 82,8\% siswa tuntas belajar, dan Siklus II 89,7\% siswa tuntas belajar. Peningkatan siswa yang tuntas belajar Pra Siklus ke Siklus I 34,5\%, dan Siklus I ke Siklus II 6,9\%.

Hasil penelitian menyatakan modele-learning dan media video dapat meningkatkan hasil belajar tematik Kelas III MI NU 33 Johorejo Kecamatan Gemuh Kabupaten Kendal Tahun Pelajaran 2019/2020.

\section{KESIMPULAN}

Hasil penelitian Kelas III MI NU 33 MI NU 33 Johorejo Kecamatan Gemuh Kabupaten Kendal Tahun Pelajaran 2019/2020, dapat disimpulkan bahwa model e-learning dan media video dapat meningkatkan hasil belajar tematik Kelas III MI NU 33 Johorejo Kecamatan Gemuh Kabupaten Kendal. Dapat dibuktikan dengan peningkatan hasil belajar Pra Siklus adalah 14 siswa $(48,3 \%)$ tuntas, dan 15 siswa $(51,7 \%)$ tidak tuntas dengan nilai rata-rata 71,2, Siklus I adalah 24 siswa $(82,8 \%)$ tuntas, dan 5 siswa $(17,2 \%)$ tidak tuntas dengan nilai rata-rata 87,9, dan Siklus II terdapat 26 siswa $(89,7 \%)$ tuntas, dan 3 siswa (10,3\%) tidak tuntas dengan nilai rata-rata 89. Peningkatan ketuntasan belajar dari Pra Siklus ke Siklus I 34,5\%, dan Siklus I ke Siklus II 6,9\%. Hal ini berdasarkan peningkatan hasil belajar pada Pra Siklus 48,3\%; Siklus I 82,8\%; dan Siklus II 89,7\%.

\section{DAFTAR PUSTAKA}

Abdul Majid. (2005). Perencanaan Pembelajaran Mengembangkan Standar Kompetensi Guru, Bandung : Remaja RoSDakarya.

Allen, Michael. (2013). Michael Allen's Guide to E-learning. Canada: John Wiley \& Sons. Arikunto. (2007). Manajemen Penelitian. Jakarta: Rineka Cipta.

Chandrawati, Sri Rahayu. (2010). Pemanfaatan E-learning dalam Pembelajaran. Untan.2 (8): 11-21.

E. Mulyasa. (2013). Pengembangan dan Implementasi Kurikulum 2013. Bandung : Remaja RoSDakarya.

Fitrah, Muh \& Luthfiyah. (2018). Metodologi Penelitian: Penelitian Kualitatif, Tindakan Kelas, \& Studi Kasus. Sukabumi: Jejak.

Hamid, Hamdani. (2013). Pengembangan Sistem Pendidikan di Indonesia. Bandung: Pustaka Setia 
Kastolani. (2014). Model Pembelajaran Inovatif:Teori dan Aplikasi. Jawa Tengah:

Kemendikbud. (2014). Konsep dan Implementasi Kurikulum 2013. Jakarta: Kementrian Pendidikan dan Kebudayaan

Kemendikbud. (2016). Buku Guru Tematik KELAS III, Jakarta:Kemendikbud.

Kemendikbud. (2016). Buku Siswa Tematik KELAS III, Jakarta:Kemendikbud.

Kristanto, Vigih Hery. (2018). Metodologi Penelitian Pedoman Karya Tulis Ilmiah (KTI). Yogyakarta: Deepublish Publisher.

Kunandar. (2014). Penilaian Autentik (Penilaian Hasil Belajar Peserta Didik Berdasarkan Kurikulum 2013): Suatu Pendekatan Praktis Disertai dengan Contoh. Ed. Rev. Jakarta: Rajawali Pers.

Kunandar. (2011). Penelitian Tindakan Kelas. Jakarta: PT Raja Grafindo

L. Tjokro, Sutanto. (2009). Presentasi yang Mencekam. Jakarta: Elex Media Komputindo.

N. Imamah. (2012).Peningkatan Hasil Belajar TEMATIK Melalui Pembelajaran Kooperatif Berbasis Konstruktivisme TEMATIKD kan dengan Video Animasi Materi Sistem Kehidupan Tumbuhan. Jurnal Pendidikan TEMATIK Indonesia. 1 (1). 32-36.

Ni Wayan AS, I Gusti N, J, Ni Wayan A. (2016). Penerapan Project Based Learning BerbantuanVideo untuk Meningkatkan Aktivitas dan Hasil Belajar TEMATIK di SD. E- Journal PGSD Universitas Pendidikan Ganesha. 4(1). 1-11

Nursalam dan Ferry Efendi. (2008). Pendidikan dalam Keperawatan. Jakarta: Salemba Medika. Permendikbud No 64 Tahun 2013 Tentang Standar Isi Pendidikan Dasar dan Menengah

Pranoto, Alvini.dkk. (2009). Sains dan Teknologi. Jakarta: PT Gramedia Pustaka Utama. Rusman. (2015). Pembelajaran Tematik Terpadu. Depok: PT Rajagrafindo Persada.

Sadiman Arief S dkk. (2012). Media Pendidikan: Pengertian, Pengembangan, dan Pemanfaatannya. Jakarta: PT Raja Grafindo Persada

Samatowa Usman. (2011). Pembelajaran TEMATIK di Sekolah menengah pertama. Jakarta:PT indeks

Sudjana, Nana. (2013). Penilaian Hasil Proses Belajara Mengajar. Bandung: PT Remaja Rosidakarya

Susanto Ahmad. (2013). Teori Belajar dan Pembelajaran di Sekolah menengah pertama. Jakarta: PT Kharisma Putra Utama

Susanto, Ahmad. (2013). Teori Belajar dan Pembelajaran di Sekolah. Jakarta: Kencana Prenada Group

Suyadi. (2015). Panduan Penelitian Tindakan Kelas. Jogjakarta: Diva Press.

Trianto. (2015). Model Pembelajaran Terpadu. jakarta: Bumi Aksara

Vardana n, r. (2016). Pengaruh Media Pembelajaran E-Learning Berbasis Edmodo pada Mata Pelajaran Penerapan Rangkaian Elektronika untuk Meningkatkan Hasil Belajar Siswa Kelas XI Teknik Audio Video di SMK Negeri 3 Surabaya. Jurnal Pendidikan Teknik Elektro. 5 (3). 689 - 696.

Wena, Made. (2009). Strategi Pembelajarn Inovatif Kontemporer (Suatu tinjauan konseptual operasional). Jakarta: Bumi Aksara.

https://www.kompas.com/edu/read/2020/03/17/121116571/panduan-5-tahap-proses-belajardi-rumah-untuk-sekolah-dan-orangtua?page=all (diakses 9mei2020) 